\title{
Welfare Implications of Capital Account Liberalization
}

\author{
Ester Faia* \\ Universitat Pompeu Fabra
}

August 2006

\begin{abstract}
In recent decades, capital account liberalization in emerging economies has often been followed by a surge in capital inflows, despite the presence of severe informational asymmetries for foreign lenders. Empirical studies have shown that in emerging economies financial liberalization has led to an increase in consumption volatility (also relative to output). I use a small open economy model where foreign lending to households is constrained by an endogenous borrowing limit. Borrowing is secured by collateral in the form of durable investment whose accumulation is subject to adjustment costs. This economy is able to replicate the aforementioned stylized fact in response to various shocks (productivity, foreign demand and government expenditure). I find that financial liberalization reduces welfare since it increases the volatility of consumption and employment.
\end{abstract}

JEL Codes: E52, F1.

Keywords: endogenous borrowing limit, financial liberalization, consumption volatility.

${ }^{*}$ I thank participants at XV International Tor Vergata conference in Banking and Finance. I gratefully acknowledge financial support from the DSGE grant of the Spanish Ministry and Unicredit research grant. All errors are my own responsibility. Correspondence to: Department of Economics, Universitat Pompeu Fabra, Ramon Trias Fargas 25-27, 08005, Barcelona, Spain. Email: ester.faia@upf.edu. Homepage: http://www.econ.upf.edu/ ${ }^{\sim}$ aia. 


\section{Introduction}

It is well documented that since the mid-1980s there has been a surge in capital flows toward emerging economies and that several developing countries have undertaken reforms to remove capital controls ${ }^{1}$. This occurred despite the fact that financial markets in emerging countries are not yet well developed and that still severe informational asymmetries characterize foreign lending. Empirical evidence also shows that, contrary to conventional wisdom, for emerging countries the increase in capital flows has induced an increase in consumption volatility (even relative to that of output). This is the opposite of what we observe for industrialized economies where financial integration is typically associated with an increase in consumption smoothing possibilities. Since consumption volatility has a direct impact on agents' utility we should conjecture that financial liberalization produced welfare detrimental effects in emerging market economies.

To account for the aforementioned stylized facts and to evaluate the welfare effects of capital account liberalization I use a small open economy model where risk averse agents finance consumption and investment in durable goods with foreign lending which is constrained by an endogenous borrowing limit. Accumulable durable investment plays the role of collateral and can be seized by foreign lenders in the event of default. The main assumptions embedded in the model respond to the need of reproducing the conditions characterizing emerging market economies. Those countries are small open economies which are characterized by frictions in the financial markets and have undergone a wave of financial liberalization. The latter dimension is captured in the present model by the parameter characterizing the sensitivity of foreign lending to the value of collateral (a higher value of this parameter relaxes the limit to foreign borrowing).

I study the quantitative properties of this model economy in response to a variety of shocks: productivity, government expenditure and foreign demand shocks. Productivity and government expenditure shocks are introduced since they are typically considered as a main source of business cycle fluctuations. Foreign demand shocks are regarded in the literature as an important source

\footnotetext{
${ }^{1}$ See Lane and Milesi-Ferretti (2001), Obstfeld and Taylor (2002), Prasad, Rogoff, Wei and Kose (2005), among others.
} 
of business cycle fluctuations mostly for emerging market economies ${ }^{2}$. Government expenditure shocks play the role of demand shocks.

Consistently with empirical evidence I find that an increase in financial liberalization increases consumption volatility in response to shocks even relative to that of output. This is so since an increase in the sensitivity of foreign lending to the value of collateral has a twofold effect. Consider a shocks which boosts the economy and increases demand. First, a higher degree of financial liberalization, by relaxing the borrowing limit, induces a positive wealth effect. Indeed higher availability of foreign lending allows for a bigger increase in the demand for both durable and nondurable goods. Secondly, when an additional unit of collateral becomes available the shadow value of relaxing the liability constraint is higher the bigger the sensitivity of foreign lending to collateral. This is a distortion effect which tends to decrease the current value of durable goods relative to that of non-durable goods and induces agents to substitute durable investment with consumption.

I finally consider the welfare consequences of financial liberalization and find that it is welfare detrimental in an economy with imperfect risk sharing ${ }^{3}$. This is so since financial liberalization increases both consumption and employment volatility thereby reducing the welfare of risk averse agents. A crucial feature of the welfare analysis is the use of second order approximated solutions which allow ${ }^{4}$ to account for the effects of stochastic volatility both on first and second moments of the variables that enter agents' utility.

The rest of the paper is divided as follows. Section 2 presents related literature and empirical evidence. Section 3 presents the model and calibration. Section 4 presents the results. Section 5 concludes.

\footnotetext{
${ }^{2}$ See Mendoza (1995) and Senhadji (1998).

${ }^{3}$ It is assumed that the borrowing constraint is always binding for any level of financial liberalization. In other words, welfare decreases with respect to an increase in financial liberalization under the assumption that the financial markets are credit constrained. Obviously welfare would increase if the economy was to move from a steady state with binding credit constraints to one with non-binding ones. I do not consider this long run growth effect since it would not apply to developing countries.

${ }^{4}$ See Kim and Kim (2003) for an analysis of the inaccuracy of welfare calculations based on log-linear approximations in dynamic open economies.
} 


\section{Empirical Evidence and Related Literature}

It is well documented that in the last two decades emerging market economies have undertaken reforms that favoured financial integration and that there has been an increase in capital flows toward those countries (see Lane and Milesi-Ferretti (2001), Obstfeld and Taylor (2002), Prasad, Rogoff, Wei and Kose (2005), among others). This wave of financial integration occurred despite the fact that financial structures in emerging economies are still not yet well developed.

Conventional wisdom suggests that financial integration increases consumption smoothing and reduces macroeconomic volatility through an increase in risk sharing possibilities. To this purpose several empirical studies have analyzed the impact of an increase in capital flows on macroeconomic volatility for emerging market economies. Contrary to what expected Gavin and Hausmann (1996) and O'Donnell (2001) find a positive link between capital flows and output volatility for emerging market economies. They argue that financial integration increases risk sharing possibility (hence reduces macroeconomic volatility) only in countries with well developed financial markets, while it increases vulnerability to foreign shocks in the opposite case.

Bekaert, Harvey and Lundblad (2002), Kose, Prasad and Terrones (2003) and Prasad, Rogoff, Wei and Kose (2005) find that in emerging market economies an increase in financial openness tends to increase consumption volatility (even relative to that of output). They also point out at the limited role of international risk sharing for economies whose financial markets are characterized by higher degrees of informational asymmetries and poor financial development.

While several empirical studies agree on the positive link between financial openness and macroeconomic volatility, a large part of the theoretical literature fails to account for aforementioned observation. Most of the theoretical contributions focusing on the relation between financial integration and macroeconomic volatility have analyzed the case of industrialized countries and concluded that financial openness tends to decrease consumption volatility (see Mendoza (1994) and Baxter and Crucini (1995)) since it increases risk sharing possibilities. Some theoretical studies have shown that the impact of financial openness on macroeconomic volatility depends the source of shocks, fiscal versus monetary shocks (see Obstfeld and Rogoff (1995), Sutherland (1996)), while 
others (Heatcote and Perri (2005) and Faia (2003)) have shown that financial openness tends to decrease international co-movements in business cycles.

More recently Levchenko (2005) uses a framework with limited commitment as in Kocherlacota (1996) and shows that domestic risk sharing arrangements might deteriorate in face of financial integration. He finds that in this case individual consumption might become more volatile but aggregate consumption volatility will nevertheless decrease, a result which is still in contrast with empirical predictions.

In the present paper we propose a simple framework which combines financial frictions and capital account liberalization and tries to reconcile empirical evidence with theoretical predictions.

\section{A Small Open Economy with Endogenous Borrowing Limits on Durable Goods Investment}

The model economy features several similarities with the one considered in Kocherlacota (2000) and Chari, Kehoe and McGrattan (2005). It is a small open economy where agents' consumption and investment is subject to endogenous borrowing limit a' la Kiyotaki and Moore (1998). There are three main differences with the aforementioned studies. First, collateralizable wealth is represented by durable goods which also provide utility services (see Mankiw (1987), Miles (1992) and Iacoviello (2004)) and can be accumulated with adjustment costs. This assumption allows to reproduce persistence in response to various shocks (see Erceg and Levin (2004)). Secondly, agents supply labor endogenously. This assumption allows for a better characterization of the welfare effects of macroeconomic volatility. Third, I consider a small open economy which produces and trades with the rest of the world imperfectly substitutable goods. The last assumption allows for a better characterization of the current account dynamic.

The economy is populated by infinitely lived and risk averse agents who consume, work and invest in durable goods. Consumption and durable investment is financed through foreign lending which takes the form of non-state contingent securities and is bounded above by a fraction of the future value of the collateral - i.e. durable goods. Hence the capital flow dynamic of the small open economy is directly linked to the tightness of the borrowing limit. Investment demand for durable 
is justified since it enters the utility functions of the consumers. The assumption of a financially constrained small open economy is justified by the inability of foreign lenders to implement perfect monitoring of the investment activity. Under those circumstances the tightness of the borrowing limit depends on the degree of information asymmetry, of financial market integration and of debt repossession ability which in turn depends upon legal and institutional arrangements. The production sector of this economy is characterized by final good firms who produce with a linear production technology using labor.

\subsection{Domestic Households}

Let $s^{t}=\left\{s_{0}, \ldots . s_{t}\right\}$ denote the history of events up to date $t$, where $s_{t}$ denotes the event realization at date $t$. The date 0 probability of observing history $s^{t}$ is given by $\rho_{t}$. The initial state $s^{0}$ is given so that $\rho\left(s^{0}\right)=1$. Henceforth, and for the sake of simplifying the notation, let's define the operator $E_{t}\{\cdot\} \equiv \sum_{s_{t+1}} \rho\left(s^{t+1} \mid s^{t}\right)$ as the mathematical expectations over all possible states of nature conditional on history $s^{t}$.

Agents maximize the following expected discounted sum of utilities:

$$
E_{t}\left\{\sum_{t=0}^{\infty} \beta^{t} U\left(C_{t}\right)-V\left(N_{t}\right)+\Delta\left(\tilde{D}_{t}\right)\right\}
$$

where $N_{t}$ denotes total labour hours, consumption:

$$
C_{t}=\left((1-\alpha)^{\frac{1}{\eta}} C_{H, t}^{\frac{\eta-1}{\eta}}+\alpha^{\frac{1}{\eta}} C_{F, t}^{\frac{\eta-1}{\eta}}\right)^{\frac{\eta}{\eta-1}}
$$

is given by a Dixit-Stiglitz consumption aggregator of domestic and imported goods (with $\eta$ being the intratemporal elasticity) and $\widetilde{D}_{t}=D_{t}-\frac{\psi}{2}\left(\frac{X_{t}-\delta D_{t}}{D_{t}}\right)^{2}$ where $D_{t}$ is the real value of the stock of a durable good which is hold in positive amount for it generates utility, $X_{t}$ is investment in durable goods, $\delta$ is the depreciation rate and the function $\frac{\psi}{2}\left(\frac{X_{t}-\delta D_{t}}{D_{t}}\right)^{2}$ represents an adjustment cost function. The period utility function is separable in each of its argument. After defining

$P_{t} \equiv\left[(1-\gamma) P_{H, t}^{1-\eta}+\gamma P_{F, t}^{1-\eta}\right]^{\frac{1}{1-\eta}}$ as the domestic price index and $s_{t}=\frac{P_{F, t}}{P_{H, t}}$ as the terms of trade, optimal demands for domestic and imported goods imply the following relation:

$$
\frac{C_{H, t}}{C_{F, t}}=\frac{(1-\alpha)}{\alpha}\left(s_{t}\right)^{\eta}
$$


The household receives at the beginning of time $t$ a labor income of $W_{t} N_{t}$, where $W_{t}$ is the nominal wage. Agents can borrow and lend in the world market at an interest rate $R$ (which is assumed time invariant for simplicity). I denote by $B_{t}$ the real amount (denominated in units of domestic consumption) of the net foreign asset position. Agents can also buy and sell durables, $D_{t}$, in an internal competitive market. The price of durable in terms of consumption goods is denoted $Z_{t}$.

The sequence of budget constraints in real terms reads as follows:

$$
C_{t}+R B_{t}+Z_{t}\left(D_{t+1}-D_{t}(1-\delta)\right) \leq \frac{W_{t}}{P_{t}} N_{t}+B_{t+1}+\tau_{t}
$$

The crucial assumption in this model is that agents face borrowing constraints on the world market. As the foreign lenders are not able to fully repossess their funding, debt and its services are guaranteed as repayable up to a certain fraction of the value of the collateral (limited liability constraint). The collateral corresponds to the future value of the durable good $Z_{t+1} D_{t}$, where $Z$ is the price of the durable good. To formalize this idea I assume that domestic households face the following period-by-period endogenous borrowing constraint on debt:

$$
R B_{t+1} \leq \Omega E_{t}\left\{Z_{t+1} D_{t+1}\right\}
$$

where:

$$
\Omega<1
$$

is the fraction of the future value of the collateral that is guaranteed to be repaid. Hence $\Omega$ reflects the degree of information asymmetry, of financial market integration and of debt repossession ability of foreign lenders which in turn depends upon legal and institutional arrangements. Since increasing $\Omega$ allows to relax the borrowing limit and to increase the availability of foreign lending, I will assume that higher degree of financial liberalization is associated with higher value of $\Omega$. Notice that domestic households face limited liability but not a risk of defaulting on the debt. This implies that the borrowing constraint always holds with equality. To ensure this it is enough to assume that $\beta<R^{-1}$. 
Households choose the set of processes $\left\{C_{t}, N_{t}, B_{t+1}, D_{t+1}\right\}_{t=0}^{\infty}$ taking as given the set of processes $\left\{P_{t}, W_{t}, R, Z_{t}\right\}_{t=0}^{\infty}$ and the initial wealth $B_{0}, D_{0}$ so as to maximize (1) subject to (4) and (5). Let's define $\lambda_{t}$ as the Lagrange multipliers on constraint (5). The following optimality conditions must hold:

$$
\begin{gathered}
U_{c, t} \frac{W_{t}}{P_{t}}=-V_{n, t} \\
U_{c, t}-\lambda_{t}=\beta E_{t}\left\{R U_{c, t+1}\right\} \\
Z_{t} U_{c, t}-Z_{t+1} \Omega \lambda_{t}+\Delta_{D_{t+1}^{\sim}} \psi\left(\frac{D_{t+1}-D_{t}}{D_{t}}\right) \\
E_{t}\left\{\beta \Delta_{D_{t+1}^{\sim}}\left(1+\psi\left(\frac{D_{t+2}-D_{t+1}}{D_{t+1}}\right)+\frac{\psi}{2} \frac{\left(D_{t+2}-D_{t+1}\right)^{2}}{D_{t+1}^{2}}\right)\right\}+\beta(1-\delta) E_{t}\left\{Z_{t+1} U_{c, t+1}\right\} \\
Z_{t}=\frac{\tilde{D_{t+1}}}{U_{c, t}} \psi\left(\frac{D_{t+1}-D_{t}}{D_{t}}\right)
\end{gathered}
$$

Equation (6) gives the optimal choice of labor supply. Equation (7) gives the price of the foreign asset. Equation (8) is the efficiency condition for the intertemporal choice of the durable good. The intuition for this equation is simple. The time $t$ marginal cost of foregoing a unit of consumption (weighted by the price of the durable) is equated to its marginal gain which has three components. The direct marginal utility of an additional unit of durable investment now and in the future, $E_{t}\left\{\beta \Delta_{D_{t+1}^{\sim}}\left(1+\psi\left(\frac{D_{t+2}-D_{t+1}}{D_{t+1}}\right)+\frac{\psi}{2} \frac{\left(D_{t+2}-D_{t+1}\right)^{2}}{D_{t+1}^{2}}\right\}\right.$, the expected marginal utility of one unit of consumption postponed into the future, $\beta(1-\delta) E_{t}\left\{Z_{t+1} U_{c, t+1}\right\}$, and, for an additional unit of collateral has become available, the shadow value of relaxing the liability constraint, $Z_{t+1} \Omega \lambda_{t}$. The last equation, (9), gives the asset price.

A few comments are worth on the distortions induced by the endogenous borrowing limit and on the effects of varying $\Omega$. First, as it stands clear from equation (7) a binding borrowing constraint (which implies a positive $\lambda_{t}$ ) induces a intratemporal distortion in the value of consumption between two different dates. By defining $R_{t}^{c}=\frac{U_{c, t}}{E_{t}\left\{U_{c, t+1}\right\}}$ as the households' intratemporal price of 
consumption, when (5) binds, households face the following endogenous finance premium ${ }^{5}$ :

$$
E_{t}\left\{R_{t}^{c}-R\right\}=\frac{\lambda_{t}}{E_{t}\left\{U_{c, t+1}\right\}}
$$

This implies that it is now more costly and that a higher premium is required to perform a shift in consumption between two different dates. An increase in the parameter $\Omega$, by relaxing the borrowing limit, reduces the responsiveness of the lagrange multiplier, $\lambda_{t}$, to exogenous shocks, therefore reducing the size of the finance premium.

Secondly, as it stands clear from equation (8) a binding borrowing constraint induces an intertemporal distortion of size $Z_{t+1} \Omega \lambda_{t}$ in the value of durable consumption between two different dates. An increase in the paramter $\Omega$ has both a direct and an indirect impact on the distortion. The direct impact comes form the fact that the size of the distortion itself depends in $\Omega$.The indirect impact comes from the fact a higher value of $\Omega$, by relaxing the borrowing limit, reduces the size of $\lambda_{t}$, which enters the distortion as well. Even in this case the distortion has an impact on the finance premium of durable investment and in turn on the volatility of the durable price.

\subsection{Domestic Firms}

There is a continuum of competitive firms in the domestic economy each producing an homogenous final good. Each firm produces according to the following production function:

$$
Y_{t}=A_{t} N_{t}
$$

The cost minimizing choice of labor input implies:

$$
\frac{W_{t}}{P_{t}}=A_{t}
$$

\subsection{Open Economy Relations}

Under the small open economy assumptions we set $P_{F, t}^{*}=P_{t}^{*}$.Furthermore I assume that the law of one pice holds continuously so that $P_{H, t}^{*}=e_{t} P_{H, t}^{*}$ and $P_{F, t}^{*}=e_{t} P_{F, t}^{*}$ where $e_{t}$ is the nominal

\footnotetext{
${ }^{5}$ The present model with endogenous borrowing limit is akin to models with endogenous financing premia such as Carlstrom and Fuerst (1997) and Bernanke, Gertler and Gilchrist (1998).
} 
exchange rate. Foreign demand of home produced goods is modelled as follows:

$$
C_{H, t}^{*}=\left(\frac{P_{H, t}^{*}}{P_{t}^{*}}\right)^{\eta} C_{t}^{*}
$$

Applying the law of one price and substituting the definition of terms of trade we obtain:

$$
C_{H, t}^{*}=\left(s_{t}\right)^{\eta} C_{t}^{*}
$$

and where $C_{t}^{*}=Y_{t}^{*}$. Foreign output is taken as exogenous by domestic residents and takes the following autoregressive process:

$$
Y_{t}^{*}=\left(Y_{t-1}^{*}\right)^{\rho}+\varepsilon_{t}^{Y^{*}}
$$

\subsection{Equilibrium Conditions}

Aggregate bonds are in negative net supply and must satisfy the following conditions:

$$
R_{t+1} B_{t+1}+\Omega E_{t}\left\{Z_{t+1} D_{t+1}\right\}=0
$$

By substituting the real wage in the budget constraint of the domestic household using firms' optimality conditions we obtain an equation that links net debt accumulation to net exports as follows:

$$
R_{t+1} B_{t+1}-B_{t}=Y_{t}-\left(C_{t}+Z_{t} X_{t}\right) \equiv N X_{t}
$$

where:

$$
X_{t}=D_{t}-D_{t-1}(1-\delta)
$$

denotes investment in durable goods.

Equation (16) describes the current account dynamic which in this economy is governed by the accumulation of foreign debt.

The resource constraint in this economy reads as follows:

$$
Y_{t}=C_{H, t}+C_{H, t}^{*}+X_{t}+G_{t}
$$




\subsection{Calibration}

Preferences. Time is measured in quarters. To ensure that the borrowing constraint is always biding I assume that $\beta<R_{t}^{-1}$, therefore I set $\beta=0.96^{6}$. Utility is modeled as follows:

$$
\frac{C_{t}^{1-\sigma}}{1-\sigma}-\frac{N_{t}^{1+\tau}}{1+\tau}+\frac{\tilde{D}_{t}^{1-\gamma}}{1-\gamma}
$$

The parameter $\sigma$ is set equal to 2 as in Schmitt-Grohe and Uribe (2003) and in most models of small open economies for emerging markets. The parameter $\tau$ is set equal to 3 since it is assumed that $1 / 3$ of the time is spent working. The parameter $\gamma$ is set equal to 2 implying that preferences over durables exhibit a somewhat lower intertemporal substitution elasticity than the logarithmic case; this value falls within the range estimated by the empirical literature.

Technology. Consistently with Erceg and Levin (2002) I set $\psi=600$. The quarterly depreciation rate of the durable stock is set to $\delta=0.025$; this value is consistent with a specification of the durable investment which includes both consumer durables and residential investment. I set the baseline parameter that defines the tightness of the endogenous borrowing limit so as to induce a steady state debt to equity (leverage) ratio of 0.4. Following Backus, Kehoe and Kydland (1995) the elasticity of substitution between home and foreign consumption, $\eta$, is set to 1.5. Finally the share of home consumption good, $\alpha$, is chosen such that the steady state sum of exports and imports is 40 percent of output.

Stochastic processes. Following Prescott (1986) and McCallum and Nelson (1999) the standard deviation of the productivity shock is set to 0.007 and its persistence is set to $0.95^{7}$. To determine

\footnotetext{
${ }^{6}$ We focus on the case in which the collateral constraint binds since the dynamic of the model in the opposite case would look exactly as the one that characterize a standard RBC model with endogenous labor supply and trade in imperfectly substitutable goods.

${ }^{7}$ There is little consensus about the statistical properties of the productivity shock in emerging market economies. For example Senhadji (1997), Mendoza and Smith (2006) and Mendoza (2006) choose (different) values for the variance and the persistence of TFP which allow to reproduce GDP volatility for various emerging market economies. Aguiar and Gopinath (2005) show that for emerging market economies a productivity process that allows to fit the data should contain both a permanent and a transitory component, a conclusion contested by Garcia-Cicco, Pancrazi and Uribe (2006). Kydland and Zarazaga (2003) show that a TFP process with a persistence of $\rho=0.56$ and a standard deviation of $\frac{1}{(1-\rho)^{2}}$ can fit well Argentinian business cycle. Given the lack of consensus I have chosen a standard RBC parametrization for the productivity process. This is a conservative parametrization which allows to appreciate better the contribution of the borrowing constraint to the model dynamic. It is important to notice however that I have performed several sensitivity analysis on the shock processes and the that the main quantitative results remained unaffected.
} 
the statistical properties of the foreign demand shock I measure world output as U.S. real GDP and using OECD quarterly data for the period 1970-2001 I seek for innovations by fitting an autoregressive process with time trend. I find that $\sigma_{\varepsilon_{t}^{Y^{*}}}=0.00885$. The share of government expenditure over GDP in the steady state is set equal to 0.2 . Finally the calibration of the government expenditure shock follows Carmichael, Keita and Samson (1999) who estimate for emerging market economies a process with a persistence of 0.46 and a standard deviation of 0.14 percent.

The set of optimality conditions of the optimal plan can be described as follows:

$$
E_{t}\left\{\mathcal{H}\left(\Psi_{t+1}, \Psi_{t}, X_{t+1}, X_{t}\right)\right\}=0
$$

where $E_{t}$ denotes the mathematical expectations operator, conditional on information available at time t, $\Psi_{t}$ is the vector of endogenous non-predetermined variables, and $X_{t} \equiv\left[x_{1, t}, x_{2, t}\right]$ is the state vector. The solution of the model is of the form (Schmitt-Grohe and Uribe (2004)) :

$$
\begin{gathered}
\Psi_{t}=g\left(X_{t}, \bar{\xi}\right) \\
X_{t+1}=h\left(X_{t}, \bar{\xi}\right)+\bar{\eta} \bar{\xi} \varepsilon_{t+1}
\end{gathered}
$$

Equation (20) and (21) describe the policy function and the transition function respectively. I compute a second order expansion of the functions $g\left(X_{t}, \bar{\xi}\right)$ and $h\left(X_{t}, \bar{\xi}\right)$ around the deterministic steady-state.

\section{Quantitative Properties of the Model}

We now turn to the analysis of the quantitative properties of the model with two purposes in mind. First, I aim to show that the model is compatible with the main stylized facts exposed in section 2. Secondly, I use the model to evaluate the welfare effects of increasing financial liberalization.

\subsection{Dynamic Responses to Shocks}

Before analyzing the business cycle properties of the model it is instructive to illustrate the dynamic responses of selected variables to various shocks. Figure (1) shows impulse responses of selected 
variables to a $1 \%$ increase in productivity. An increase in aggregate productivity increases output and wage wealth which in turn induces an increase in consumption of both, durable and non-durable goods. The increase in the demand of durable goods induces an increase in the price of durable which in turn raises the future value of collateral. Finally, the increase in the value of collateral relaxes the borrowing limit therefore increasing the availability of loans and further raising the demand for durable and non-durable goods. As a consequence of the increase in the availability of foreign lending the current account becomes negative and terms of trade depreciate. It is worth noticing that all variables show hump-shaped dynamics; this is due to the persistence introduced by the cost of adjusting durable investment.

Figure (2) shows impulse responses of selected variables to a positive foreign demand shock. An increase in foreign demand renders positive the current account therefore inducing appreciation of the terms of trade. The positive dynamic of the current account induces an outflow of capital which reduces the availability of foreign lending, the demand of durable goods and its price. Aggregate consumption of non-durable goods increases temporarily due to the positive boosts coming from the increase in the consumption of home produced goods, but it decreases after a few periods due to the fall in the availability of lending.

Figure (3) shows impulse responses of selected variables to a government expenditure shock. An increase in government expenditure crowds out the demand for durable and non-durable consumption. The price of the durables falls and consequently the value of collateral decreases. This tightens the borrowing limit and reduces the availability of foreign lending.

\subsection{Consumption Volatility and Financial Openness}

Figure (4) shows changes in the volatility of consumption with respect to changes in the tightness of foreign lending described by the parameter $\Omega$. The model has been solved under both productivity and foreign demand shocks, as they are considered the main source of fluctuations in emerging market economies. I find that consumption volatility is monotonically increasing with respect to the degree of financial openness. This is so since an increase in the parameter $\Omega$ has a twofold

effect. First, there is a wealth effect due to which an increase in $\Omega$ makes the borrowing limit 
less tight therefore increasing the availability of foreign lending for every size of the shock. The increase in the availability of foreign lending allows for a bigger increase in the demand for both durable and non-durable goods. Secondly, as it stands clear from equation (8) when an additional unit of collateral becomes available the shadow value of relaxing the liability constraint, $Z_{t+1} \Omega \lambda_{t}$ is higher the bigger is the size of $\Omega$. This is a distortion effect which tends to decrease the current value of durable goods relative to that of non-durable goods and induces agents to substitute durable investment with consumption. We observe indeed that while the sensitivity of non-durable consumption in response to shocks increases when $\Omega$ increases, the contrary is true for the demand in durable goods.

To check robustness I also study the effects of trade openness (as measured by the ratio of exports over GDP $\alpha$ ) on consumption volatility and find little effect ${ }^{8}$, a result consistent with empirical evidence (see Easterly, Islam and Stiglitz (2001) and Kose, Prasad and Terrones (2003)).

Furthermore, I find that consumption volatility relative to output volatility also increases with respect to $\Omega$. Indeed relative consumption volatility goes from 0.9049 to 0.9962 when $\Omega$ goes from 0.2 to 0.8. This result is consistent with Bekaert, Harvey and Lundblad (2002), Kose, Prasad and Terrones (2003) and Prasad, Rogoff, Wei and Kose (2005) who point out that the increase in consumption volatility cannot be associated with crises episodes since we also observe an increase in relative (to output) consumption volatility.

\subsection{Welfare Implications}

The critical feature of the analysis so far conducted consists in evaluating the impact of capital flow liberalization on household's welfare. We have shown previously that an increase in financial openness induces an increase in macroeconomic volatility, hence we are now interested in assessing its impact on welfare. To fully account for the effects of the increased volatility on welfare I solved the model using second order approximations ${ }^{9}$ which allow to account for the effects of stochastic

\footnotetext{
${ }^{8}$ Results are not reported for brevity but are available upon request.

${ }^{9}$ See Kim and Kim (2003) for an analysis of the inaccuracy of welfare calculations based on log-linear approximations in dynamic open economies. See Kim et al. (2003) and Schmitt-Grohe and Uribe (2004a) for a more general discussion.
} 
volatility both on first and second moments of the variables in the model ${ }^{10}$.

The welfare metric employed is given by the conditional expectation of the second order Taylor expansion of agents' utility:

$$
\mathcal{W}_{0}=\left\{E_{0} \sum_{t=0}^{\infty} \beta^{t} U\left(C_{t}, N_{t}, \tilde{D}_{t}\right)\right\}
$$

Figure (5) shows changes in welfare with respect to changes in the parameter $\Omega$ ranging from 0.4 to 0.8 . Agents' welfare is clearly decreasing with respect to the parameter defining the degree of financial liberalization. The reason for this is simple. A raise in in the parameter $\Omega$ increases both the volatility of consumption and employment. Since agents are risk averse the increase in volatility reduces welfare. Notice that this occur despite the fact that the volatility of durable goods is decreasing with respect to the same parameter.

Before closing it is worth exploring whether the negative link between welfare and financial openness remains unchanged for different values of the elasticity of demand for durables. This parameter indeed affects the volatility of durable goods. More specifically the higher is the value of $\gamma$ the lower is the volatility of durable goods in response to shocks. Figure (6) shows changes in welfare with respect to changes in the parameter that defines financial openness, $\Omega$, and for two different values of $\gamma$ (1.5 in the top panel graph and 3 in the bottom panel graph). Financial openness remains welfare detrimental for every value of the elasticity for durable goods. Additionally we observe that higher values of $\gamma$ by reducing the volatility of durables tend to raise welfare.

\footnotetext{
${ }^{10}$ Since in a first order approximation of the model's solution the expected value of a variable coincides with its non-stochastic steady state, the effects of volatility on the variables' mean values is by construction neglected. Hence we can fully appreciate the effects of volatility on welfare only by resorting to a higher order approximation of the policy functions.
} 


\section{References}

[1] Aguiar, Mark, and Gita Gopinath. (2004) "Emerging Market Business Cycles: The Cycle is the Trend". NBER w.p. 10734.

[2] Backus, David K., Kehoe Patrick J. and Kydland, Finn E. (1992) "International Real Business Cycles". Journal of Political Economy, 101, 745-775.

[3] Baxter, Marianne and Mario Crucini. (1995) "Business cycles and the Asset Structure of Foreign Trade". International Economic Review, 36, 821-54.

[4] Bekaert, G., C.R. Harvey, and C. Lundblad. (2002) "Growth Volatility and Equity Market Liberalization". Manuscript.

[5] Bernanke, Ben, Mark Gertler, and Simon Gilchrist. (1999) "The Financial Accelerator in a Quantitative Business Cycle Framework", in J.B. Taylor, and M. Woodford, eds., Handbook of Macroeconomics, Amsterdam: North-Holland.

[6] Carlstrom, Charles, and Timothy Fuerst. (1997) "Agency Costs, Net Worth and Business Fluctuations: A Computable General Equilibrium Analysis." American Economic Review, 87, 893-910.

[7] Carmichael, Benoit, Sikoro, Keita and Lucie Samson. (1999) "Liquidity Constraints and Business Cycles in Developing Countries". Review of Economic Dynamics 2, 370-402.

[8] Chari, V.V., Kehoe, Patrick J. and McGrattan, Ellen R. (2005) "Sudden Stops and Output Drops." Research Department Staff Report, Federal Reserve Bank of Minneapolis.

[9] Christiano, Lawrence, Gust, Christopher and Roldos, Jorge. (2004) "Monetary Policy in a Financial Crisis", Journal of Economic Theory, 119(1) pp.64-103.

[10] Cicco, Javier G., Roberto Pancrazi, and Martin Uribe. (2006) "Real Business Cycles in Emerging Countries?". Manuscript, Duke University. 
[11] Cooley, Thomas F. and Hansen, Gary D. . "The Inflation Tax in A Real Business Cycle Model." American Economic Review, 1989, 79:733 748.

[12] Easterly, W., R. Islam, and J.E. Stiglitz. (2001) "Shaken and Stirred: Explaining Growth Volatility". Annual World Bank Conference on Development Economics, ed. by B. Pleskovic and N. Stern.

[13] Faia, Ester. (2005) "Finance and International Business Cycles". Forthcoming Journal of Monetary Economics.

[14] Gavin, M., and R. Hausmann. (1996) "Sources of Macroeconomic Volatility in Developing Economies". W.P. Inter-American Development Bank.

[15] Glick, Reuven, and M. Hutchinson. (1999) "Banking and Currency Crises: How Common are Twin Crises?". In R. Glick, R. moreno, and M. Spiegel (Eds), Financial Crises in Emerging Markets, Cambridge University Press.

[16] Heathcote, Jonathan, and Fabrizio Perri. (2004) "Financial Globalization and Real Regionalization." Journal of Economic Theory, 199(1), 207-243.

[17] Iacoviello, Matteo. (2005) "House Prices, Borrowing Constraints and Monetary Policy in the Business Cycle". American Economic Review, 95, 739-764.

[18] Iacoviello, Matteo, and Raoul Minetti. (2003) "Financial Liberalization and the Sensitivity of House Prices". Manchester School, 71(1).

[19] Kamisnky, Graciela, and Carmen M. Reinhart. (1999) "The Twin Crises: The Causes of Banking and Balance of Payments Problems". American Economic Review, 89, 473-500.

[20] Kehoe, Patrick J. and Perri, Fabrizio. (2000) "International Business Cycles With Endogenous Incomplete Markets." Econometrica.

[21] Kiyotaki, Nobuhiro and Moore, John. (1997) "Credit Cycle." Journal of Political Economy, 105(2), pp. 211-48. 
[22] Kydland, Finn E., and Carlos E. J. M. Zarazaga. (2002) "Argentina's Lost Decade". Review of Economic Dynamics, 5, 152-165.

[23] Kose, M.A., E. Prased and M. E. Terrones. (2003) "How Does Globalization Affect Synchronization of Business Cycles". American Economic Review Papers and Proceedings.

[24] Lane, Philip, GianMaria Milesi-Ferretti. (2001) "The External Wealth of Nations: Estimates of Foreign Assets and Liabilities for Industrial and Developing Countries". Journal of International Economics, 55, 263-94.

[25] Levchenko, Andrei. (2005) "Financial Liberalization and Consumption Volatility in Developing Countries". IMF Staff Papers 52, 2.

[26] Mendoza, Enrique G., (1994) "The Robustness of Macroeconomic Indicators of Capital Mobility". In Leonardo Leiderman and Assaf Razin (Eds.), Capital Mobility: the Impact on Consumption, Investment and Growth, Cambridge University Press, 83-111.

[27] Mendoza, Enrique. (2006) "Endogenous Sudden Stops in a Business Cycle Model with Collateral Constraints: A Fisherian Deflation of Tobin's Q". Manuscript, University of Maryland.

[28] Mendoza, Enrique, and Katherine, Smith. (2006) "Quantitative Implications of a Debt Deflation Theory of Sudden Stops and Asset Prices". Forthcoming Journal of International Economics.

[29] Miles, David. (1992) "Housing Markets, Consumption and Financial Liberalization in Major Economies". European Economic Review, 36, 1093-1127.

[30] Neumeyer, Pablo A. and Perri, Fabrizio. (2004) "Business Cycle in Emerging Economies: The Role of Interest Rates". NBER 1.p. 10387.

[31] Obstfeld, M., and K. Rogoff. (1995) "Exchange Rate Dynamics Redux". Journal of Political Economy, 103, 624-60. 
[32] Prescott, Edward. (1986) "Theory Ahead of Business Cycle Measurement". Carnegie Rochester Series on Public Policy, 24:11-44.

[33] Schmitt-Grohe, Stephanie and Uribe, Martin. (2003) "Closing Small Open Economy Models". Journal of International Economics, 61, 163-185.

[34] Senhadji, A.. (1997) "Sources of Debt Accumulation in a Small Open Economy". IMF w.p.

[35] Senhadji, A.. (1998) "Dynamics of Trade Balance and the Terms-of Trade in LDCs: The S-Curve". Journal of International Economics, 46, 521-39.

[36] Sutherland, Alan, "Financial Market Integration and Macroeconomic Volatility". Scandinavian Journal of Economics, 98, 521-39. 

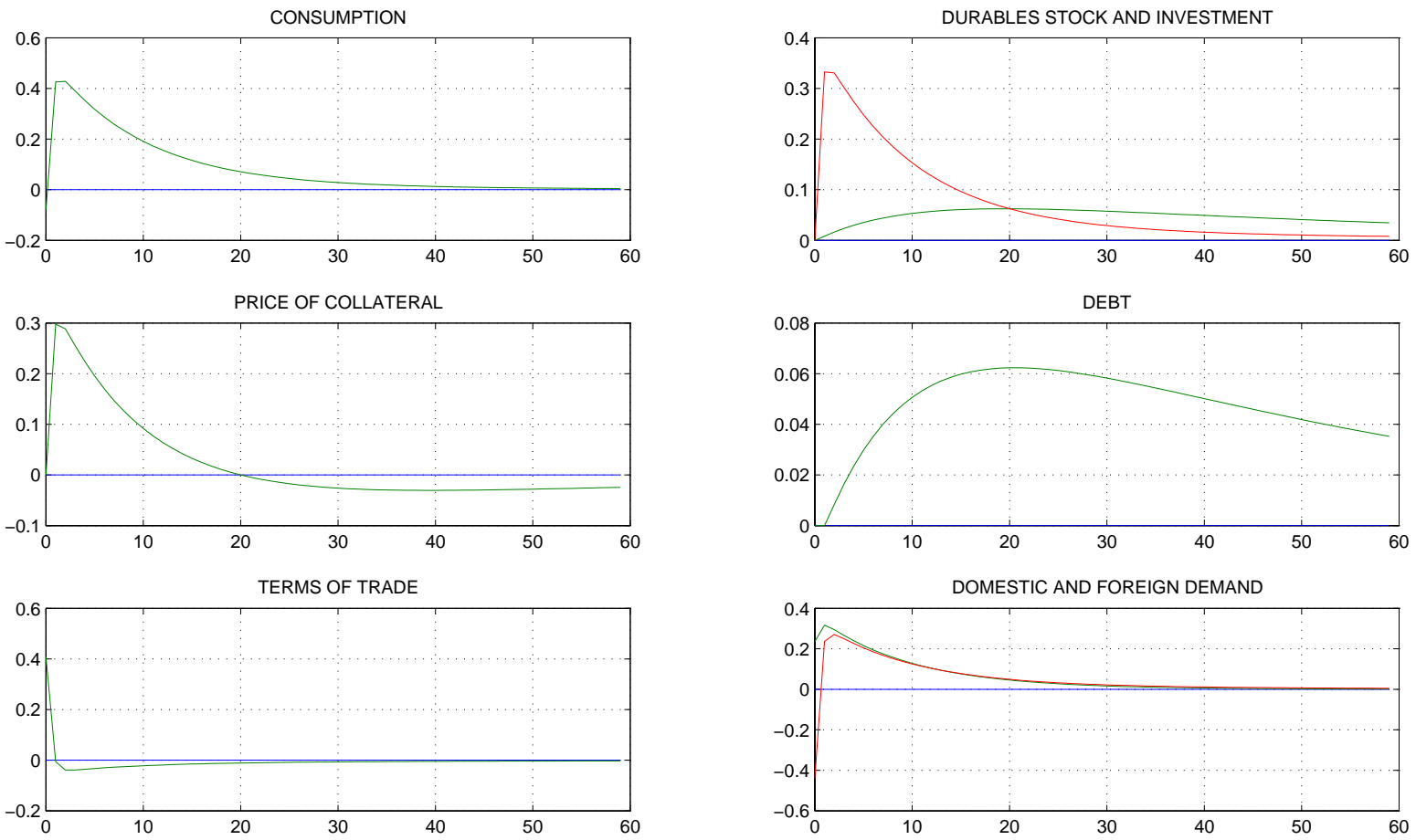

Figure 1: Impulse responses to domestic productivity shocks. 

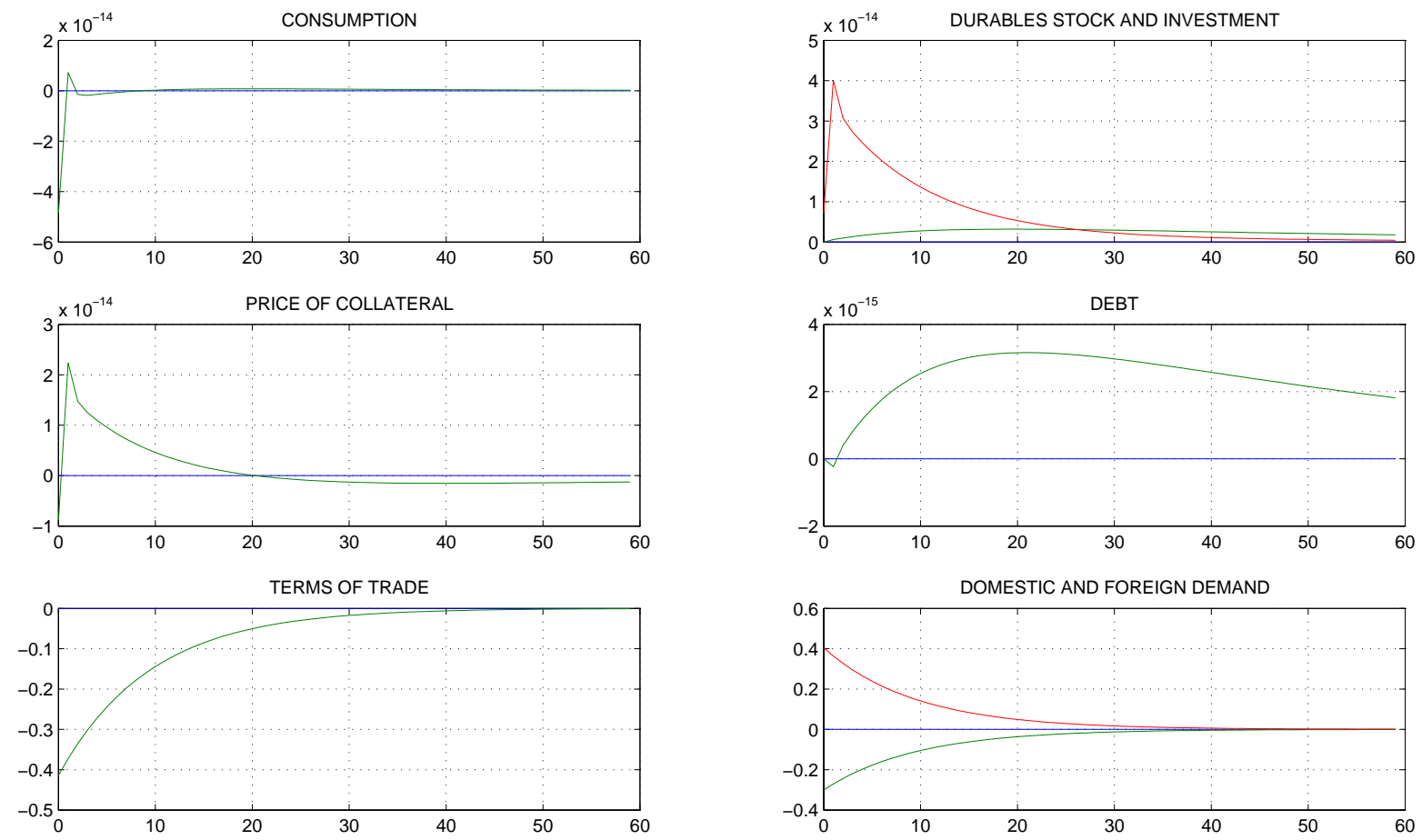

Figure 2: Impulse responses to foreign demand shocks. 

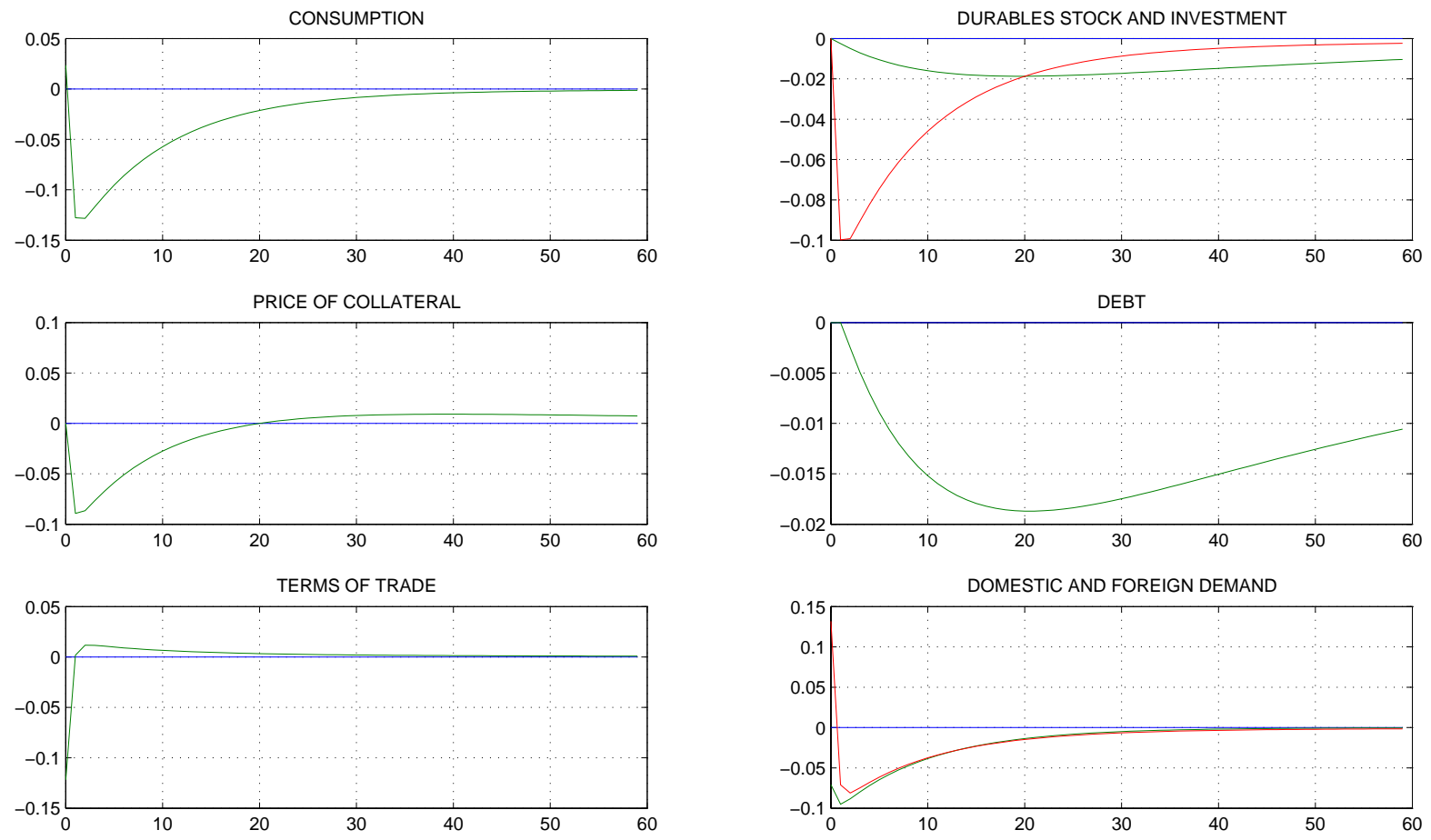

Figure 3: Impulse responses to government expenditure shocks. 


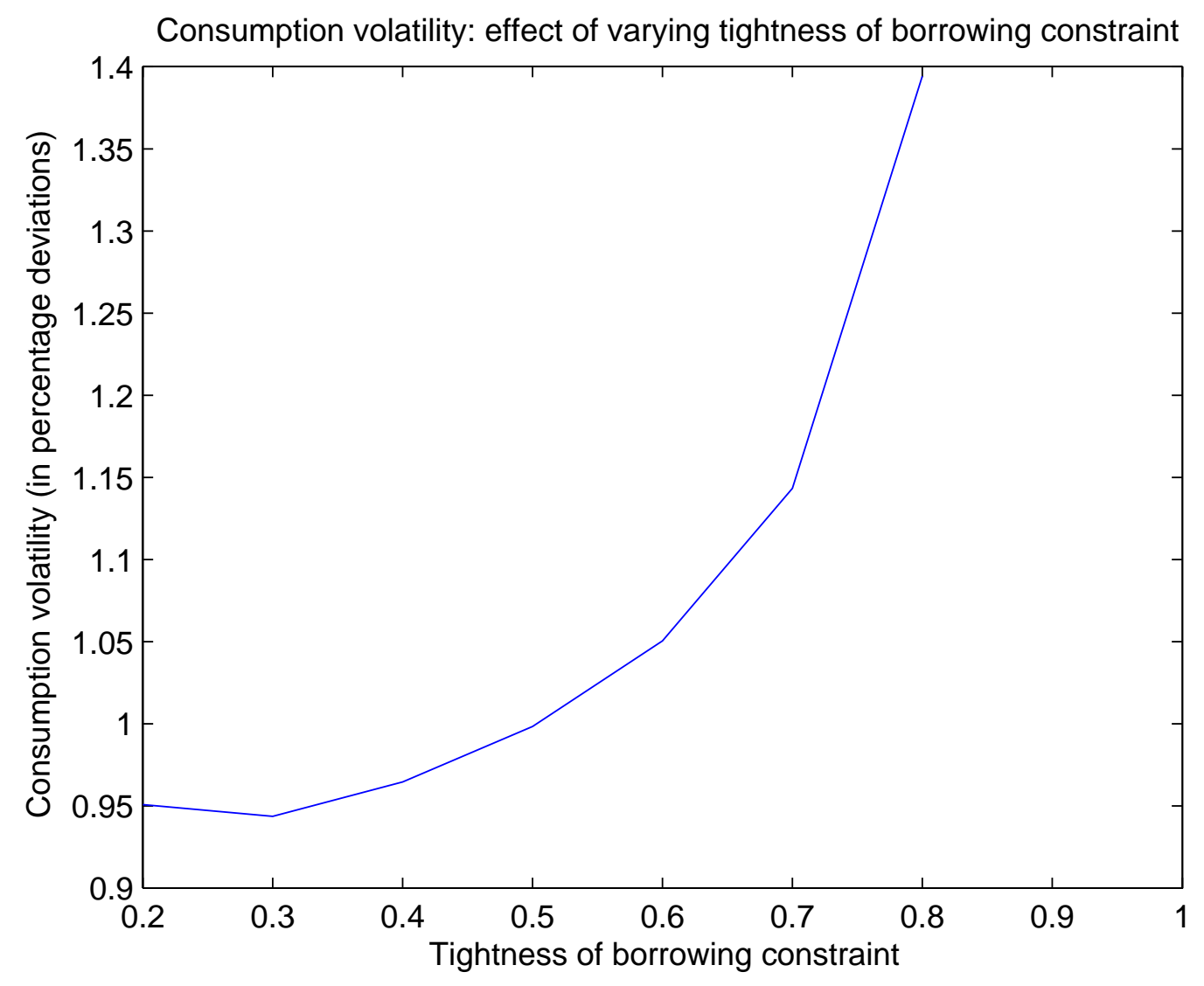

Figure 4: 


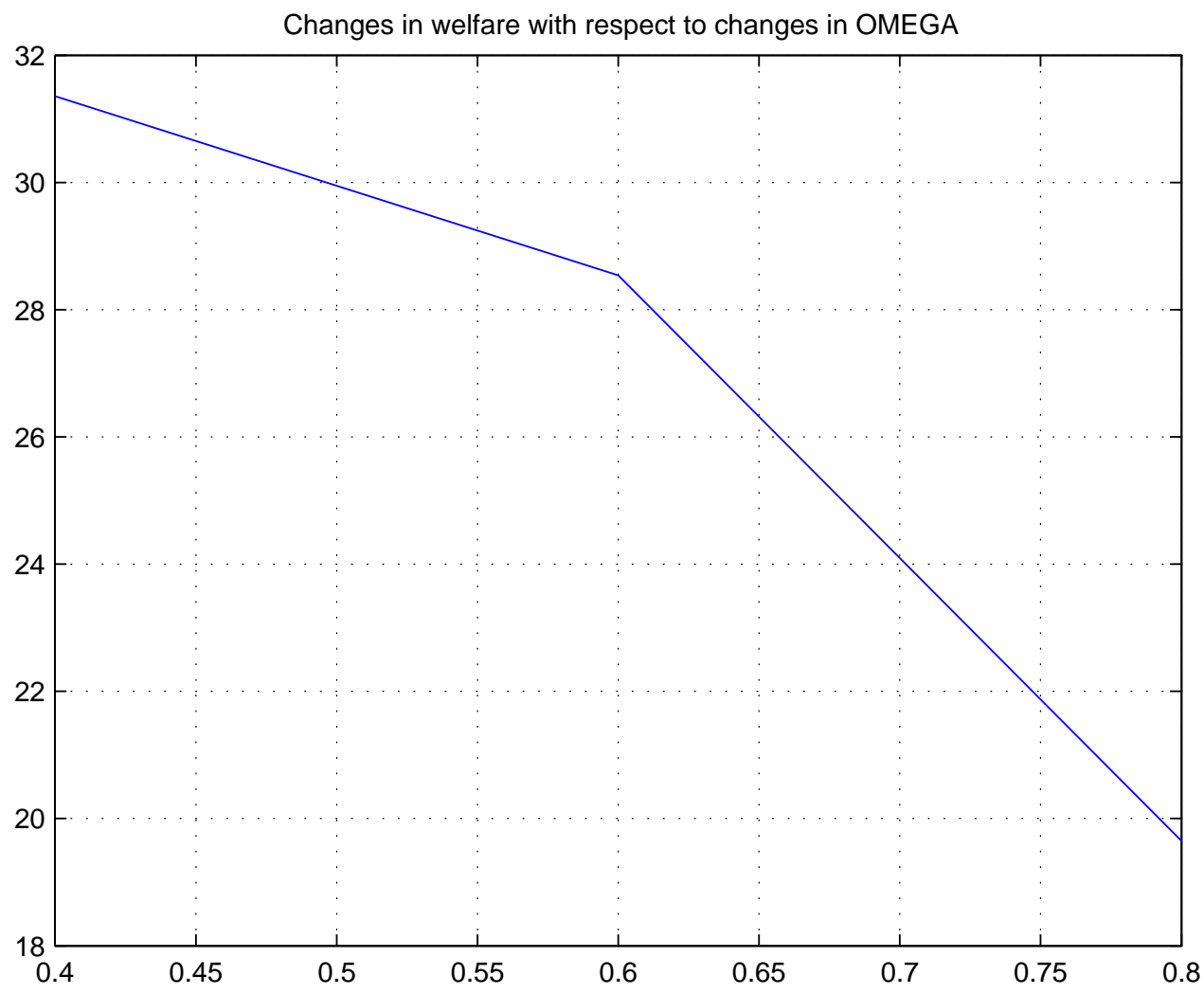

Figure 5: 

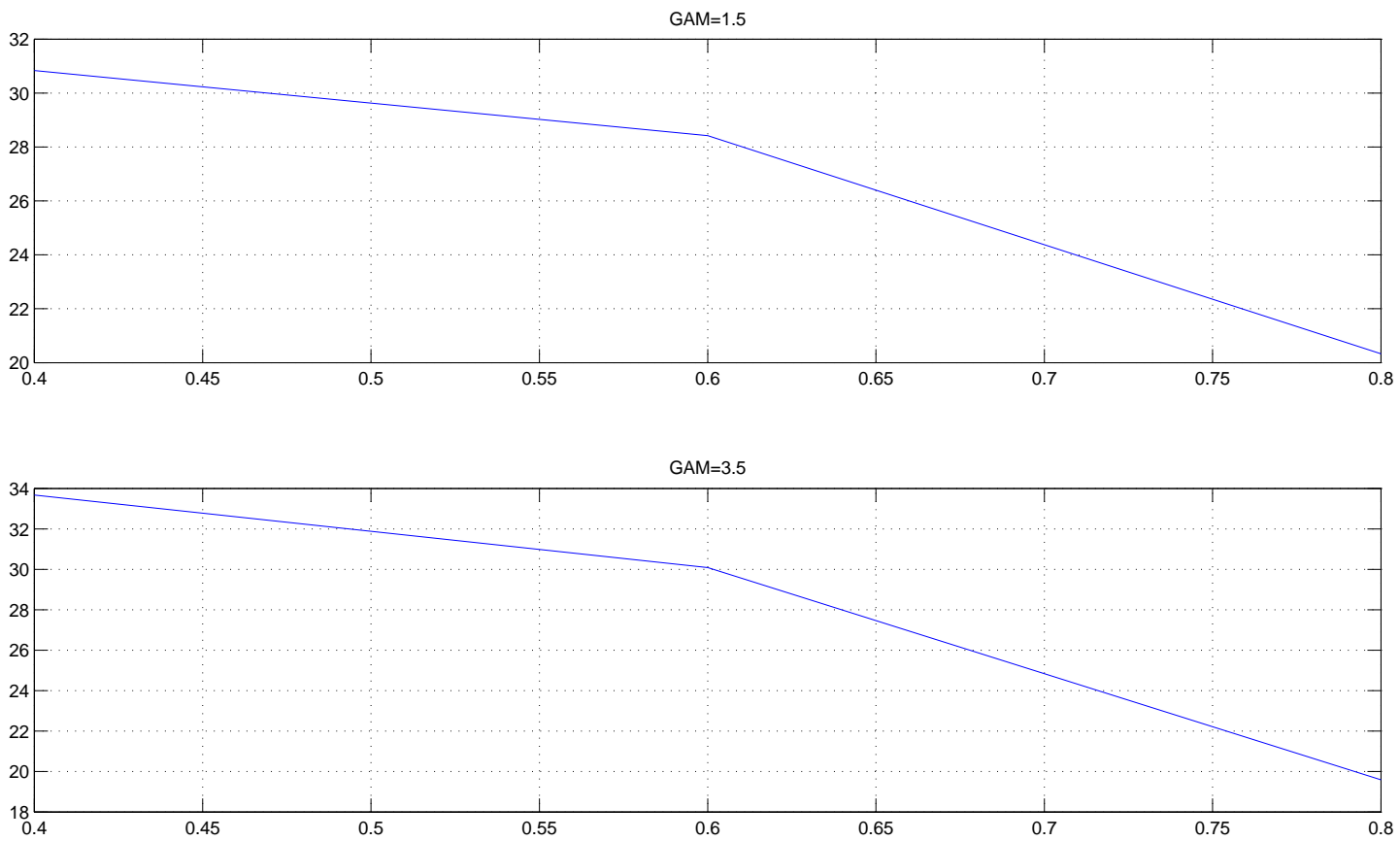

Figure 6: Changes in welfare with respect to changes in financial openness for two different values of $\gamma$. 